\title{
Current state of the urban network in Bulgaria
}

Estado atual da rede urbana na Bulgária

Estado actual de la red urbana en Bulgaria

L'état actuel du réseau urbain en Bulgarie

\section{Veselin Petkov and Milen Penerliev}

\section{OpenEdition}

\section{Journals}

\section{Electronic version}

URL: http://journals.openedition.org/espacoeconomia/16962

DOI: 10.4000/espacoeconomia.16962

ISSN: 2317-7837

\section{Publisher}

Núcleo de Pesquisa Espaço \& Economia

\section{Electronic reference}

Veselin Petkov and Milen Penerliev, «Current state of the urban network in Bulgaria », Espaço e Economia [Online], 19 | 2020, Online since 02 September 2020, connection on 10 December 2020 URL : http://journals.openedition.org/espacoeconomia/16962 ; DOI : https://doi.org/10.4000/ espacoeconomia.16962

This text was automatically generated on 10 December 2020 .

\section{(c) (i) (8)}

Espaço e Economia - Revista brasileira de geografia econômica est mise à disposition selon les termes de la licence Creative Commons Attribution - Pas d'Utilisation Commerciale - Partage dans les Mêmes Conditions 4.0 International. 


\title{
Current state of the urban network in Bulgaria
}

\author{
Estado atual da rede urbana na Bulgária \\ Estado actual de la red urbana en Bulgaria \\ L'état actuel du réseau urbain en Bulgarie
}

Veselin Petkov and Milen Penerliev

\section{Classification and hierarchical organization of cities}

It is believed that cities emerged later than villages. Cities (urban settlements) are settlements whose population is mainly employed in industry, commerce, the services sector, governance, education, science and culture. The current Administrative and Territorial Structure of the Republic of Bulgaria Act envisages that for a village to be declared a town, it has to have a population of over 3500 inhabitants and a relevant social and technical infrastructure.

Cities emerged during different socio-economic conditions. As part of the ancient world, Greek cities existed in our days Bulgarian territory, mainly along the Black Sea coast, Thracian settlements occupied the interior of the country, while later Roman settlements began to appear. There are very few remains of medieval Bulgarian cities and fortresses, mostly because of their destruction by the Ottomans. Although the Ottoman Turks only built few cities, they changed the appearance of the existing ones through the construction of mosques, bazaars, madrasas, hammams, fountains, etc. The improvement of the economic well-being of the Bulgarians during the Bulgarian Renaissance period, resulted in the construction of many original Bulgarian houses and public buildings, clock towers, churches and fountains, preserved to this day in settlements such as Kotel, Zheravna, Koprivshtitsa, Tryavna, Bansko and many more. Thus, according to the cultural and religious influence they were under, cities ended up with different overall appearance, while the terrain itself has also been a factor in urban planning. 
In 1936 the prominent Bulgarian geographer Prof. Ivan Batakliev divided the urban settlements in the country as follows:

- Southern European type - located on steep terrains, with narrow streets - such as Veliko Tarnovo, Lovech, the Old town of Plovdiv, etc.

- Oriental type - urban settlements in the plains with vast yards - such as Kazanlak, Ruse, etc.

- Modern type - urban settlements with wide and straight streets - Stara Zagora, Sofia, Nova Zagora, etc.

But, one of the first classifications of the urban settlements in Bulgaria was proposed by Konstantin Irechek in 1899, when he divided them into two main types: 1) Agricultural towns and 2) Crafts-and-trade towns. This was the first division of Bulgarian urban settlements by functionality.

In the Post-World War II period of Bulgaria the division of cities by predominant functions assumed a more scientific and differentiated character.

Nowadays, the most commonly adopted division provides that urban settlements in Bulgaria are functionally divided into five main categories (Donchev and Karakashev, 2015):

with capital functions (Sofia)

with complex functions (Varna, Plovdiv, etc.)

multifunctional (i.e. combining at least 3 economic activities or industries: Shumen, Dobrich, etc.)

with two main functions (with different variations between the leading sector transport, tourism, agriculture, etc.). For example, Gorna Oryahovitsa is a town with industrial-transport function, while Velingrad exhibits tourist-industrial function.

monofunctional (such as Madan, Rudozem, Laki, Belovo, Bankya, Sozopol, Varshets, etc.).

The classification of urban settlements can also be based on their geographical location Black Sea towns, Danubian, Plain, Mountainous.

The classification of urban settlements by leading industrial activity is also widely used:

- Mining: Bobov Dol, Radnevo, etc.

- Transport services: Cherven Bryag, Gorna Oryahovitsa, etc.

- Industrial-agrarian: Karlovo, Karnobat, etc.

- Agro-industrial: Dulovo, Mizia, etc.

- Recreational tourism and balneology: Nesebar, Balchik, Varshets, Hisarya, etc.

It has to be taken into consideration, however, that urban functions represent a dynamic category and change over time.

By number of population, as of 2018, cities can be divided into:

- ones with over a million residents (Sofia - 1.3 million);

- largest - over 100000 residents. This group includes 6 cities - Plovdiv (372 thousand), Varna (352 thousand), Bourgas (214 thousand), Ruse (152 thousand), Stara Zagora (147 thousand) and Pleven (107 thousand);

- large - between 50 thousand and 100 thousand residents - Sliven, Dobrich, Shumen, Pernik, Haskovo and some others. 
- medium-sized - between 20000 and 50000 residents - Silistra, Sevlievo and some others.

- small - under 20000 residents - Provadia, Karnobat, Nesebar and many others.

The smallest town in Bulgaria is Melnik with 263 residents as of the end of $2018^{1}$.

One of the recently proposed classifications is the one adopted by the National Spatial Development Concept $\left(\mathrm{NSDC}^{2}\right)$ and other planning and strategic documents. In that case, urban settlements are grouped into five hierarchical levels. The main criterion used is the functional role of the settlement, as well as the city's influence on the adjacent territory. The area of influence of a central city of each hierarchical level coincide with the following boundaries:

urban settlement of level 5 - the boundaries of the municipality itself (the lowest administrative-territorial level in the country, LAU 1);

urban settlement of level 4 - a group of municipalities;

urban settlement of level 3 - a district (NUTS 3);

urban settlement of level 2 - a planning region (NUTS1)

urban settlement of level 1 (the capital city) - the whole country

According to this classification, only Sofia is a city of first hierarchical level, while six cities (Plovdiv, Varna, Burgas, Ruse, Stara Zagora and Pleven) are of the second level. There are 28 other third-level cities, most of them regional centers (NUTS 3), the smallest of them being Razgrad (population of 30 thousand people). There are 90 urban settlements in the level 4 group (e.g. Balchik, Sevlievo, Madan, Sozopol, etc.). These are mostly municipal centers. The smallest urban settlements represent the 5th hierarchical level of local importance only (e.g. Koprivshtitsa, Simeonovgrad, Zemen, etc.). This last group also includes several villages, which function as municipal centers. The average population number of the settlements of level 5 is about $2.5-3$ thousand inhabitants. To a large extent, this classification overlaps the widely-used division by population size outlined above.

\section{Number of population in urban settlements}

During the 30-year period (the so-called transition al period) after the fall of communism, the urban population of Bulgaria exhibits a relatively steady number (5.7 million as of 1995 compared to 5.1 million as of 2019). The decrease of over 0.5 million is mainly due to the processes of emigration - mostly abroad, but also to rural settlements within the country. Over 2.6 million people reside in cities with a population of more than 100 thousand people, which accounts for $51 \%$ of the urban population and $38 \%$ of the total population of Bulgaria. This represents a serious disproportion that has its negative effects. The cities of Sofia, Plovdiv, Varna and Burgas are increasing their population and concentrate vast demographic resources. For level 5 urban settlements, however, the trends are just the opposite: most of them have been shrinking since 1990 (Zemen, Malko Tarnovo, Dospat, etc.), while others had began to depopulate much earlier (Klisura, Merichleri, etc.). Some of those small towns today do not even have a functioning secondary school (for example - Chiprovtsi). Unemployment rates in small towns are well above the national average (for example in the small town of Antonovo, the unemployment rate is around 28\%). 


\section{The capital city}

Sofia has been the capital of Bulgaria since April 3, 1879. At that time it had a population of just under 12 thousand people, which was less than that of Ruse, Varna and Shumen, while its urban area was just 3 sq.km. A century later, Sofia had reached the benchmark of one million residents (in the early 1980s). Nowadays, at the end of 2019, 1.3 million people live in Sofia (National Statistical Institute, 2020). For 140 years Sofia has increased more than 100 times. Currently 19\% of the country's population reside in the capital city. The age structure of Sofia's population is as follows: under working age - $15.3 \%$; in working age - $64.3 \%$ (60\% national average) and above working age $-20.4 \%$ ( $24 \%$ national average). Compared to the national average, it can be seen that the age structure of the capital's population is more favorable. The share of working population is larger, while that of the residents above working age is lower than the national average. The territorial distribution of the population in the city is uneven. It is evident that more than 100000 people live in the city districts of Mladost, Studentski Grad and Lyulin - resembling the population number of second-level cities. The unemployment rate in Sofia was only $1.8 \%$, while the average wage was BGN 1700 (around 850 EUR) as of the end of 2019 (compared to the national average of about BGN 1200 or 600 EUR).

\section{Small monofunctional towns}

The analysis of monofunctional urban settlements is difficult due to the fact that the very assignment of settlements to this group is controversial. The time vector often changes the specialization of such settlements: for example, in the early 1990s Sozopol was a town with two main functions (tourism and food industry), while nowadays only tourism is the activity that provides livelihood to the local population. In the context of the analysis, it is also important to take into account the geographical location of those towns - the town of Madzharovo for example is monofunctional, where lead and zinc ores mining is the only industrial activity, an industry now limited to a small area in the Rodopi Mountains. Seaside resort monofunctional towns, on the other hand, have a much better geographical location and the negative processes observed are less intensive.

Table 1 shows the main indicators for the towns of Sozopol, Kozloduy and Laki. All three are monofunctional, one of them with declining mining functions (Laki), another one - with rapidly developing seaside tourism along the Black Sea (Sozopol), while Kozloduy is the center of nuclear energy in Bulgaria and a promising developing town.

Table 1: Demographic indicators for selected monofunctional towns in Bulgaria ${ }^{3}$

\begin{tabular}{|l|l|l|l|}
\hline Indicator & Sozopol & Kozloduy & Laki \\
\hline $\begin{array}{l}\text { Population number (15 Dec. } \\
2018) *\end{array}$ & 5104 & 13259 & 2161 \\
\hline Depopulation rate (\%)** & -13.5 & +4.1 & 0 \\
\hline $\begin{array}{l}\text { Unemployment rate (\%, as of } \\
\text { 2019) }\end{array}$ & 7.0 & 12.5 & 5.1 \\
\hline
\end{tabular}

*by current address

**2007 - base year; Civil Registry Office data 
The analysis of Table 1 shows surprising trends. A seaside town such as Sozopol, which should be developing with priority given the current economic conditions in the country, exhibits the highest depopulation rate. The specialization of this monofunctional town in tourism provides some justification for the observed negative trend: turism in Bulgaria is strongly seasonal and therefore employment is temporary. Often, those working in resort complexes come from the inland. On the other hand, in purely economic terms, the financial benefits from providing various tourist services to the town are undeniable.

Kozloduy is the largest town by population among the three in discussion. It is a center of nuclear energy and concentrates specialists of high professional status, from around the country, who work in the nuclear power plant, which to a great extent explains the population growth. Laki on the other hand is a mining town. During the studied period it did not exhibit depopulation - a process which we can assume began in the early 1990s and ended shortly after. Today the mines around the town are still operating, providing jobs to the local population. The unemployment rate therefore is the lowest, but that is based also on the smallest population number the town has compared to the other two. The high unemployment in Kozloduy is related to the population of lower educational status, facing serious difficulties in finding jobs in the town. Unemployment figures are shown at the municipal level, which in the case of Kozloduy, worsens additionally the indicator's value. For comparison, the average unemployment rate in Bulgaria as of January 2020 was $3.7 \%$.

Small towns exhibit a clear population aging trend - the share of the population of above working age is far higher than the national average. For example, in the small towns of Chiprovtsi and Zemen that share is $40.7 \%$ and $40.5 \%$ respectively - twice the national average.

Small towns often have only one source of income (livelihood). This makes residents entirely dependent on it and in case of negative change of the economic conditions can seriously affect the employment of the local population. This leads to increased unemployment, economic migration and ultimately - to depopulation - the most serious threat to small towns.

\section{The largest cities}

This paper adopts the classification where cities a population of over 100 thousand inhabitants are considered as "largest cities". Those (as of the beginning of 2020) are: Plovdiv, Varna, Burgas, Ruse and Stara Zagora. These 5 cities have a total population of 1165 thousand people, which constitutes $17 \%$ of the total population of Bulgaria. Both the capital city of Sofia and the group of largest cities concentrate some 2.5 million people, or more than $1 / 3$ rd of the country's total population. This disproportion leads to problems both in big cities and in the smaller ones (in the latter case depopulation). The capital city and the cities of Varna, Plovdiv and Burgas tend to increase their population. Geographically, two of the large cities are located along our Black Sea coast (Varna and Burgas), one on the Danube River (Ruse) and the rest (Sofia, Plovdiv and Stara Zagora) are relatively evenly distributed across southern Bulgaria.

Common positive features of the largest cities are the low unemployment rates (below the national average), better age structure of the population and easy access to 
specialized health care services. The average salary in those cities is also above the national average.

The number of registered unemployed in Varna at the end of 2019 was 3108, or 313 less compared to the end of 2018 . The unemployment rate in the city was $1.8 \%$, or by 0.2 percentage points lower than it was as of June the previous year.

The unemployment rate in the city of Burgas was also $1.8 \%$ at that same moment of observation, while the level of the indicator was below $4.0 \%$ in the city of Stara Zagora (Employment Agency data).

The major problems which the largest cities face are related to air pollution, increased traffic and difficult access to some social services. In terms of air pollution, Sofia is ranked 21st in Europe (www.airvisual.com/world-most-polluted-cities), while the city of Ruse comes 31st.

The largest city in Bulgaria - Sofia, was recently included in the list of cities by traffic congestion index, maintained by the navigation systems manufacturer TomTom. Last year, the Bulgarian capital's debut placed the city straight in the top 100 of the world ranking, where 23 other European cities occupy higher positions in the list. This puts us in the middle of both charts (pollution and traffic congestion), as the cities surveyed worldwide are a total of 189, including just over 40 in Europe.

Sofia is ranked 83rd with an average traffic slowdown of $29 \%$. During the morning rush hours it takes $58 \%$ more time to commute, while during the afternoon rush hour - $66 \%$ (www.maxo.bg).

It can be seen from Table 2 that the natural reproduction indicators in the largest cities are better than the national average. In 2019 the country's natural population growth is negative (population decline) - minus $6.5 \%$. In the largest cities, it is also negative, but only in the range between minus $1 \%$ and minus $2 \%$. This is not, however, the case in small towns, where the natural population growth in some cases reaches values of minus $30 \%$. The share of population above working age in all largest cities of the country is around $17 \%$, which is lower than the national average. Due to the better living conditions, the developed infrastructure and the better labor market, these cities represent the leading university centers in Bulgaria. The capital city of Sofia alone concentrates almost $50 \%$ of all university students in the country.

Table 2: Selected indicators for the largest cities in Bulgaria

\begin{tabular}{|l|l|l|l|l|l|}
\hline City & $\begin{array}{l}\text { Crude birth rate } \\
(\%)\end{array}$ & $\begin{array}{l}\text { Crude death } \\
\text { rate } \\
(\%)\end{array}$ & $\begin{array}{l}\text { Natural growth } \\
(\%)\end{array}$ & $\begin{array}{l}\text { Number of } \\
\text { university } \\
\text { students } \\
\text { (tsd) }\end{array}$ & $\begin{array}{l}\text { Share } \\
\text { population } \\
65+(\%)\end{array}$ \\
\hline Sofia & 10.4 & 11.6 & -1.2 & 105 & 17 \\
\hline Plovdiv & 10.0 & 11.8 & -1.8 & 37 & 17.6 \\
\hline Varna & 9.6 & 11.0 & -1.4 & 28 & 17 \\
\hline Burgas & 9.2 & 11.4 & -2.2 & 7 & 17.5 \\
\hline
\end{tabular}

souRce: European cities statistics (www.nsi.bg), 2018

\section{Spatial organization of cities agglomeration areas}

In both academic and strictly scientific geographical literature, two types of urban agglomerations in Bulgaria had been adopted until recently - "formed" and "in formation". Nowadays the term is still in use, but for a limited scope of research and in 
some legal acts ${ }^{4}$. A more justified and practically applicable category of a lower rank is the agglomeration area. Unlike the agglomeration, it has a leading city (agglomeration core) with a population of over 50 thousand inhabitants ${ }^{5}$. Given the general trend of population decline in the country as a whole, the agglomeration area will be representative for the better part of the country. The territorial scope of these areas is defined by the municipalities, respectively - the settlements in the area of influence of the agglomeration core (where more than $15 \%$ of the labor force commutes daily (Socio-economic Analysis of the Regions in the Republic of Bulgaria, Second Stage, 2019).

At present, there are 18 agglomeration areas in the country, whose centers (cores) are: Sofia, Plovdiv, Varna, Burgas, Ruse, Stara Zagora, Pleven, Shumen, Dobrich, Yambol, Sliven, Haskovo, Pazardzhik, Blagoevgrad, Pernik, Vratsa, Veliko Tarnovo and Gabrovo. These agglomeration areas consist of a total of 61 municipalities, covering $25 \%$ of the country's territory. Over 4 million people, or some $60 \%$ of the population of Bulgaria, reside in those areas. Out of that population, $75 \%$ are concentrated in the core cities themselves. This fact, as well as the above-mentioned concentration of population in cities over 100 thousand inhabitants, shows that the population is extremely unevenly distributed throughout the country. This creates problems for both the agglomeration areas and the depopulated areas in Bulgaria.

Figure 1. Agglomeration areas in Bulgaria

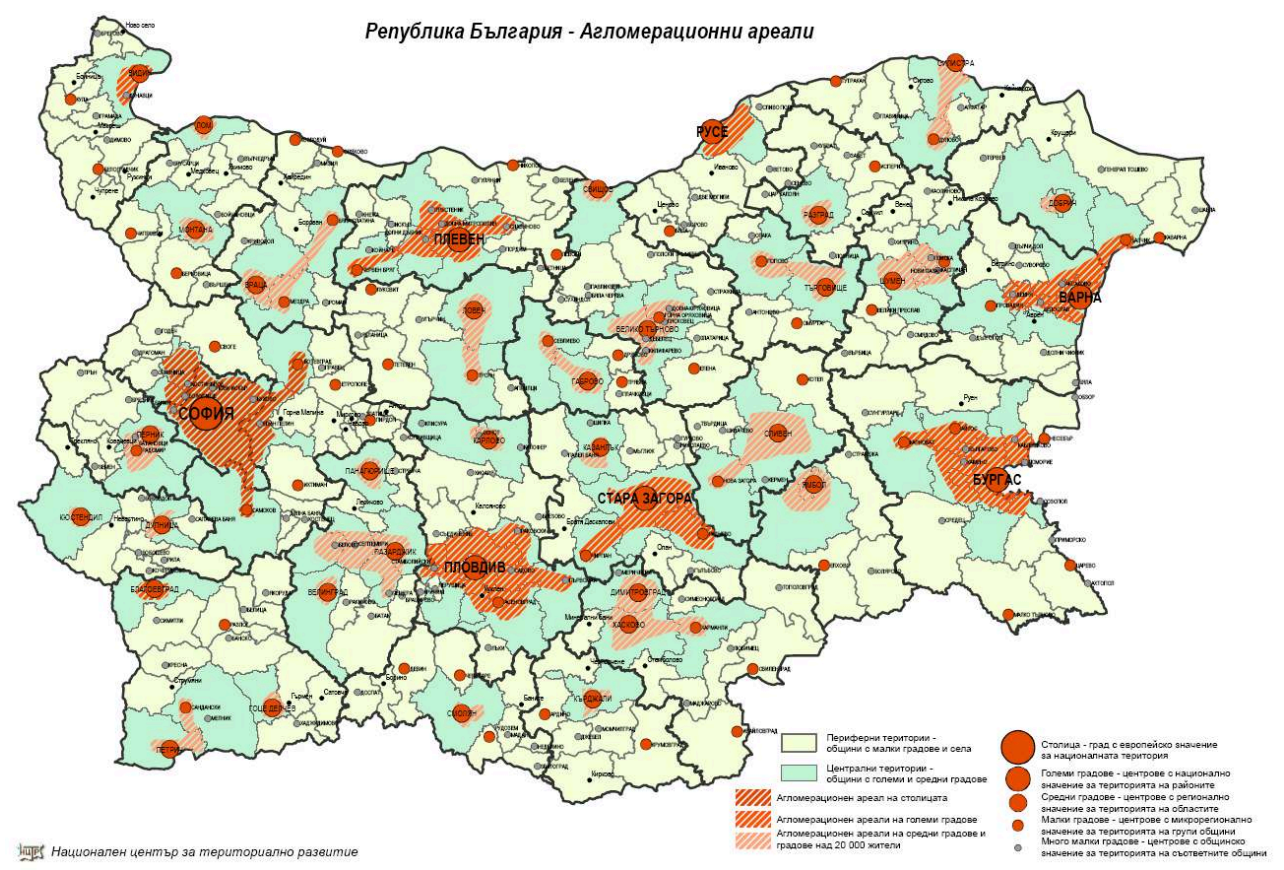

source: The National Center for Regional development

Today, cities continue to develop. The downside to the urban development is the increasing concentration of population in powerful zones of influence around just 2-3 major cities. This further triggers depopulation processes throughout the rest of the country and puts those depopulated areas at risk. 


\section{Conclusion}

The urban settlements in Bulgaria are developing at different "speeds". Small towns do not actually develop - they are declining, both demographically and in purely economic terms. The opposite happens with the largest cities and the capital city - they "suck out" the country's population, thus increasing the spatial disparities and increasing the problems in other (smaller) urban settlements. The standard of living the largest cities is higher, all demographic indicators exhibit better values, but at the same time those large cities have severely worsened their environmental status. Modern agglomeration processes in the country are limited mostly to the largest cities' zones of influence.

\section{BIBLIOGRAPHY}

DONCHEV D.; H. KARAKASHEV. Geography of Bulgaria, Siela publ. Sofia, (in bulgarian), 2015.

ILIEVA, V. Social demographic aspects, part. 1, University of Shumen "Konstantin

Preslavski"publ., Shumen, (in bulgarian), 2019.

PENERLIEV, M. On the necessity of studying the monofunctional towns in Bulgaria, Proceedings

of the Bulgarian Geographical Society, issue 41 (in bulgarian), 2019.

PETKOV, V.; Penerliev, M. Geography of the population, settlements and regions in Bulgaria, Incoma publ. Shumen, (in bulgarian), 2020.

Socio-economic Analysis of the Regions in the Republic of Bulgaria, Second Stage, 2019.

http://www.bgregio.eu/media/files/Programirane\%20\&\%20ocenka/

Programirane\%202014-2020/NKPR\%20proekt.pdf

www.nsi.bg (24.02.2020)

www.maxo.bg (1.03.2020)

www.grao.bg (1.03.2020)

www.airvisual.com/world-most-polluted-cities (29.02.2020)

\section{NOTES}

1. By current address

2.

http://www.bgregio.eu/media/files/Programirane\%20\&\%20ocenka/ Programirane\%202014-2020/NKPR\%20proekt.pdf

3. Penerliev, M. On the necessity of studying the monofunctional towns in Bulgaria, Proceedings of the Bulgarian Geographical Society, issue 41, 2019 
4. For example the Ministry of Regional Development and Public Works maintains a register of the agglomerations for the needs of certain legal acts (e.g. the Environment Noise Protection Act).

5. This minimum threshold is not accidental and meets the European criterion for a cluster of type "city" for the purposes of comparability between other agglomeration areas is the EU.

\section{ABSTRACTS}

The paper deals with the classification of urban settlements in Bulgaria in a historicalgeographical aspect, focusing on the genesis and the formation of today's urban network in the country. The current state of the capital city, the small and the large cities have been revealed through certain examples. Those three groups of urban settlements develop at a different place, under different conditions and face an ambiguous future. In urbanization aspect, the agglomeration areas in Bulgaria have also been analyzed as specific spatial formations.

O artigo trata da classificação dos assentamentos urbanos na Bulgária num aspecto históricogeográfico, centrando-se na génese e na formação da atual rede urbana do país. 0 estado atual da capital, das pequenas e das grandes cidades tem sido revelado através de certos exemplos. Estes três grupos de aglomerados urbanos desenvolvem-se a um ritmo diferente, em condições diferentes e enfrentam um futuro ambíguo. No aspecto da urbanização, as áreas de aglomeração na Bulgária foram também analisadas como formações espaciais específicas.

El artículo trata de la clasificación de los asentamientos urbanos en Bulgaria en un aspecto histórico-geográfico, centrado en la génesis y en la formación de la actual red urbana del país. El estado actual de la capital, de las pequeñas y de las mayores ciudades ha sido revelado a partir de ciertos ejemplos. En estos tres tipos de aglomerados urbanos desarrollan-se en un ritmo diferente, en diferentes condiciones y enfrentan un futuro ambiguo. En el aspecto de la urbanización, las áreas de aglomeración en Bulgaria he sido analizadas como formaciones espaciales específicas.

Cet article vise à montrer la classification des établissements urbains sous le point du vue historico-géographique, en soulignant la genèse et la formation de l'actuel réseau urbain en Bulgarie. La capitale, les petites et les grandes villes possèdent ses spécificités et ne se développent pas selon les mêmes rythmes. Le résultat, c'est que son avenir est ambigu.

\section{INDEX}

Palabras claves: asentamientos urbanos, red urbana; Bulgaria.

Keywords: urban settlements; urban netword; Bulgarian.

Mots-clés: établissements urbains, réseau urbain, urbanisation, dimension historicogéographique, Bulgarie.

Palavras-chave: Assentamentos urbanos; rede urbana; Bulgaria. 


\section{AUTHORS}

\section{VESELIN PETKOV}

University of Shumen "Bishop Konstantin Preslavski", Bulgaria. Department "Geography, regional development and tourism". E-mail: veselin_9003@abv.bg.

\section{MILEN PENERLIEV}

University of Shumen "Bishop Konstantin Preslavski”, Bulgaria. Department "Geography, regional development and tourism”. E-mail: penerliev@yahoo.com. 